\title{
ARCHAEOLOGISTS FROM LVOV IN THE FORMATION OF EUROPEAN INTELLECTUAL ENVIRONMENT OF THE MIDDLE OF XIX - FIRST QUARTER OF XX CENTURY (INTERACTION DIRECT AND INDIRECT)
}

KEYwORDs: Austrian Empire; ukrainian archeology; scientific contacts; archaeologists of Lvov; Galicia

SŁowa Kluczowe: Cesarstwo Austriackie; archeologia ukraińska; kontakty naukowe; lwowscy archeolodzy; Galicja

\section{Archaeologists of Lvov and European science}

In XIX century Lvov was a true European city. For example, recall that it was the capital of the Kingdom of Galicia and Lodomeria. Regional Sejm and residence of vicegerent were in the city. Decent development of science and education was provided by the University and Polytechnic Institute, where the best professors worked. European image of Lvov was clearly emphasized by theaters ("Theatre of Skarbek" was opened in March, 1842 and at the period of its opening it was the third largest theater in Europe), museums (Dzieduszycki's and Lubomirski's ones) library of Ossolineum, founded in 1817 in Vienna and ten years later moved to Lvov. According to the famous historian of archeology Stefan Karol Kozłowski (2006: 90) 'this city, the fact completely forgotten now, at those times was by a head above Kraków of Stanisław Wyspiański and the Wawel".

Of course, Lvov archeology itself could not be something separate and closed. It evolved in the same direction as the European science in general. We can reasonably affirm that scientists from Lvov knew well the most advanced achievements of this time, recent archaeological news, communicated with colleagues. Today we can often hear that science has no borders, and analyzing 
documents of XIX century we assured that for archaeological science this sentence was true throughout its history.

The first connections of Lvov with European archeology should be associated with the stage of collecting. In the end of XVIII - beginning of XIX century interest in collecting of antiquities spread through aristocratic elite of Europe. Its most rich representatives visited Italy and then - Greece. However, there were less wealthy antiquarians who could not allow themselves costly trip to Italy, so they tried to examine the local antiquities. Thus, during the period which in the history of development of archaeology is defined as Romanticism, the "national archeology" appeared. It opposed the classic one. Romantically minded antiquarians were interested mostly in medieval antiquities - runes, druids, burial mounds, castles as instrument of self-assertion and rising of national recognition (Klejn 2011: 210). So, Romanticism was closely connected with the nationalliberation movements on the one hand and with reaction to the revolution on the other.

On the territory of the Western Ukraine Jan Wagilewicz (1811-1866) (fig. 1) carried out romantic study of antiquities. He was a man of encyclopedic knowledge, a typical representative of his era. J. Wagilewicz was one of the first who began to study "runic inscriptions", shrines of druids, burial mounds. Working with the problems, which were actual in different parts of Europe in the end of the 1830s he correspondence with the famous Slovakian scientist Pawer Szafarik (1795-1861) (fig. 2). Archaeological themes took an important place in this communication. In 1839 in periodical editions an information appeared about the early medieval (as was defined by J. Wagilewicz) medal, found during field works in Sadzhava near Bogorodchany (now Ivano-Frankivsk region). In a letter to P. Szafarik he dated the medal to the end of XII century. He also made the assumption that it could be brought from Kyiv during the rule of Roman Mstyslavovych (Mścisławowicz) (Vagy'levy`ch 1928: 945).

In the middle of XIX century European archeology progressed noticeably. From this period we can talk about archeology as a scientific discipline. Among the major events which influenced on the formation and development of science it is worth to note adoption of the system of three ages, that was developed and basically published in 1836 in the "Guide by the museum" by Danish scientist Christian Thomsen (1788-1865) (Klejn 2011: 218). Researches, carried out by Boucher de Perth (1788-1868) was another important step. Scientist connected the discovery of stone tools with bones of extinct animals and on this base he argued existence of human long before the Great Flood. These opinions are well harmonized with the discoveries of Charles Darwin (1809-1882) and with 
his ideas of evolution. In a short time after the 1859 British researchers August Henry Pitt-Rivers (1827-1900) and John Evans (1823-1908) began to organize artifacts in evolutionary series, which began the using of typological method in chronological constructions and allow to trace the continuity of cultures. This idea was developed in the next years by Swedish scientist Oscar Montelius (18431921) (Renfrew, Bahn 2002: 25). This list can be continued, but another fact is important there: whether researchers from Lvov know about these "novelties" in archeology, did they used new methods of researches, and finally, had they personal contacts with leading archaeologists of Europe? And the answer to this question is affirmative.

Analysis of printed materials, reports, correspondence makes it possible to affirm that from the middle - last quarter of XIX century Lvov archaeological center was not only closely familiar with European archeology by literature, but also many researchers were directly involved to archaeological life of Europe. Mentioned facts only confirm this sentence.

The exhibitions remain at that time one of the most common ways of advertising. In XIX century the World Exhibitions launched in Europe. The first one took place in 1851 in London and only the industry was represented there. However, these exhibitions give each country an opportunity to show themselves from different sides, so soon was offered to display different collections - artistic, ethnographic and archaeological. In 1873 the exhibition was at the first time presented outside France and Great Britain - in Vienna. Włodzimierz Dzieduszycki, famous in the cultural environment of Lvov of the middle of XIX century was the organizer of Galicia part of exhibition. His archaeological activity was presented at the previous publications of the author (Buly'k 2008a: $412-413 ; 2008$ b). Interestingly, that the heads of exhibition is not allowed to separate Galicia department, but W. Dzieduszycki presented the exposition in a such way, that it was significantly different from other parts of the exhibition (Karolczak 2001: 108). We do not find any mentions about archaeological materials, presented on this exhibition.

A somewhat different situation can be seen at the exhibition conducted in 1878 in Paris. W. Dzieduszycki headed the Austro-Hungarian delegation. Exhibition materials was represented in the catalogue (Catalogue..., 1878). W. Dzieduszycki presented "sites of Stone Age, discovered in Galicia" and a variety of ethnographic materials. Interestingly, that W. Dzieduszycki also took to Paris Mykhalkiv hoard. Information about this was given by Teodor NieczujaZiemięcki, who writes that "[...] the owner of Mykhalkiv hoard W. Dzieduszycki took it with him to Paris in order to show it to the competent specialists" 
(quote by: Bandrivs`ky`j, Krushel `ny`cz`ka 2012: 14). French catalogue includes an interesting comment:

[...] exposed patterns from W. Dzieduszycki's Ethnographic Museum, selected in order to give the analogy that exists from the perspective of shape, decoration and technical characteristics between past prehistoric period and modern home production (Catalogue... 1878: 72).

Dzieduszycki's Museum by the number of items took the second place after the host of exhibition (Abramowicz 1974: 91). For this exhibition W. Dzieduszycki received the highest award - the Order of the Iron Crown of first class (Karolczak 2001: 110).

Scientific forums played the important role in the development of archeology. International Congress of Prehistoric Anthropology and Archaeology, organized in 1866 by the initiative of the French pre-historian Gabriel de Mortillet (1821-1898) was one of the most important forums in the European context (Brézillon 1969: 160-161; Lech 2006: 30). Participation in the Congress was prestigious. First of all it was an opportunity to establish contacts, to represent own achievements to the respected scientific community, to get answers to many questions, and after all, to be a part of European intellectual environment. In 1876 in Budapest VIII-th session of Congress was organized. Eastern Galicia was also presented, by Stanisław Krzyżanowski - the president of the Regional Archaeological Society and an editor of magazine of the Society and by the author of "Encyclopedia..." - Antoni Schneider (fig. 3) (Kronika Towarzystwa...; Schneider 1877).

A. Schneider described his impressions of the Congress in details. Above all, he was able to meet personally well known scientists, including Jan Zawisza and Oscar Montelius (Schneider 1877: 126; Sadowski 1877: 11). In addition, the latest achievements of archaeological and anthropological researches in Europe was presented at the Congress. Exhibitions of antiquities, shown at the Congress impressed A. Schneider greatly. Later he admitted this at his notes (LNNB NAN: F 144, op. V, spr. 13). Every major delegation at the Congress had its own exhibition. Researchers from Lvov and Kraków exposed materials from Galicia. Generally, the exhibition has a great success and archaeologists from Galicia found out controversial moments of the dating and interpretation of finds, which previously seems doubtful for them (Sadowski, 1877: 22).

Returning from Congress, A. Schneider prepared a detailed report about the results of his visit to this international forum, and published a record about this trip on the pages of "Przegląd Archeologiczny". Impressed by the speeches at the Congress, the researcher wrote that: 
[...] due to the progress in science we have an important task: detailed study of our past, especially the graves, densely spread on the territory of the ancient Slavs. These researches create a separate area on the field of science, called prehistoric or preChristian archaeology and reveal to us broad views of the history of ancient world (LNNB NAN: F 144, op.V, spr. 13, ark. 40).

Concerning A. Schneider's scientific contacts, it should be emphasized that he was a self-taught archeologist, but also the honorary member of the wellknown European scientific societies. In particular, the diploma of corresponding member was sent to him by Geological Institution in Vienna and by several German societies (Podgórski, 1875: 116-117).

Ukrainian archeology of Lvov in the end of XIX century developed around Tarasa Szewczenko Scientific Society and Michał Hruszewski. Contacts with Western scientific world played an important role at the activity of the Society. They were built in several areas and allow to represent worthily Ukrainian science in European environment.

For example interesting information can be found at the correspondence between Michał Hruszewski (fig. 4) and Lubor Niederle (fig. 5), which chronologically covers the period of 1898-1914. At these letters, scientists concerned a number of scientific problems, including archeology. In particular, at one letter L. Niederle in details analyzed review written by M. Hruszewski on his first monograph Lidstvo $v$ době předhistorické ze vláštním zřetelem na země slovanské (1893), and even discuss some questions (Naulko 2006: 634).

The real connecting link between Lvov and Western scientific community was an archaeologist, ethnologist and anthropologist with a worldwide reputation Fedir Vovk (fig. 6). This famous scientist lived in Paris, studied anthropology and archeology from L. Manuvriye, P. Brocka, P. Topinara, E. Ami. In addition, F. Vovk was the student of Gabriel de Mortillet and had good personal contacts with this famous scholar. F. Vovk not only obtained knowledge and experience in Europe, but also tried in various ways to introduce the achievements of world archeology to his colleagues from Lvov. First of all, the scientist purchased at the request of M. Hruszewski materials for the museum of Shevchenko Scientific Society. Due to F. Vovk in 1903 museum of Szewczenko Scientific Society obtained an unique samples of Acheulean hand axes from Paleolithic sites in France (Sytnyk 1999: 9). In addition, F. Vovk sent to Lvov rare finds purchased in Italy, Switzerland, Egypt (Petegyryč 1996: 61). In 1904 F. Vovk was personally involved in organizing of the archaeological collection of the Museum of Szewczenko Scientific Society (Kubijovyč 1991: 28).

Another important moment is the method of archaeological research. As a student of G. de Mortillet he does not agree with the methods used 
by Ukrainian scientists in the beginning of $\mathrm{XX}$ century and gave his recommendations for excavations of Trypillia sites. First of all, scientists considered as necessary to make plans and sections of the objects (Radiêvs'ka 2012: 215). Large summarizing article about Trypillia was published by F. Vovk on the pages of Lvov magazine "Materials for Ukrainian-Ruthenian ethnology" (Vovk 1905).

Furthermore participation of F. Vovk at the international scientific forums favored familiarization of the international community with Ukrainian archeology. Thus, in 1900 in Paris XII International Congress of pre-historians, anthropologists and archaeologists was organized. There F. Vovk presented M. Hruszewski's report "Funeral fields in Chekhy". After the publication of results of researches of burial, carried out by Ukrainian archaeologists on international level, discussion about them begins in Europe. The text of report was transferred to F. Vovk through I. Franko (Vovk 1905).

In the summer of $1903 \mathrm{~F}$. Vovk presented lectures on archeology in the Shevchenko Scientific Society in Lvov (Franko 2001: 226). He tried to present the latest achievements of western European archaeology to scientists of Lvov. During demonstration of collection brought from France, F. Vovk presented a course of lectures about archaeological periodization, created by Gabriel de Mortillet (1821-1898), whose terminology and fundamentals of chronology remained usable till now (Brézillon 1969: 161). Later the Society published it on Ukrainian language in translation, made by F. Vovk. Due to F. Vovk exchange by literature, replenishment of archaeological collection were organized too.

Polish archeology of Lvov at that time were developed on the base of Lvov University. In 1905 the University received the Chair of classical archeology and pre-history, headed by professor Karol Hadaczek (1873-1914). This young professor-archaeologist was well-educated, and important place in his education belonged to studying in the capital of the Habsburg Empire. By the recommendation of Ludwik Ćwikliński - his teacher of classical philology from Lvov, K. Hadaczek during 1897-1900 studied in Vienna (fig. 7) (he specialized in classical archaeology, prehistory and numismatics), where he attended lectures of E. Raysha, R. Boreman (DALO: F 26, op. 5, spr. 336, ark. 37; Berest 1998: 78). A special role in the process of formation of the archaeologist lectures of Austrian pre-historian Moritz Hoernes (1852-1917) (fig. 8) took place, who was one of the best pre-historians in Europe of this period (Lech 1999: 28).

Vienna at that time was one of the most important centers of science and culture among the countries of Western Europe. In the end of XIX century in Central Europe, first of all in Vienna and Berlin, cultural-historical archeology appeared, the main postulate of which were archaeological culture, the area of its 
distribution and relationships (Trigger 1989: 148-206). During his education in Vienna, K. Hadaczek studied classical and prehistoric archaeology. Since then he was closely connected with the Vienna scientific community. Studies in Vienna finished by doctorate in philosophy. In the next year K. Hadaczek received a three-year (1901-1903) research project on a trip to Greece, Italy, Germany and was able to participate in the archaeological expeditions (Abramowicz 1991: 83). During this journey K. Hadaczek perfectly mastered the technique of excavations, which allow him to evaluate critically even his own researches, carried out during previous years (Hadaczek 1914: 2-3). In Berlin he learned about ideas of Gustav Kossina (1858-1931), about original homeland of Slavs, with which he had agreed, and probably also met this scientist. In general, K. Hadaczek belonged to the small cohort of archaeologists who joined naturally to the European intellectual environment and identified themselves with it. Unfortunately, the events of the World War I and tragic finish of short life of the scholar interrupted the great work carried out by K. Hadaczek.

After the war a classical archaeologist Edmund Bulanda (1882-1951) moved to L'viv and in 1916 he headed the chair left by Karol Hadaczek. It was preceded by studies at the Jagiellonian University, which finished by doctorate in 1908 and traveled to Athens, Rome, Florence, Berlin, Asia Minor. He participated in excavations in Greece (Sytnyk 2012: 811). The knowledge obtained in Europe and accumulated materials he popularized in L'viv until his move to Wroclaw (1946). Very soon the idea of the creation of another archaeological chair - Chair of prehistory appeared. This offer was introduced by E. Bulanda in June, 1920. The newly created chair was headed by Leon Kozłowski, who undoubtedly was an equal partner for Western scientists. We will not focus special attention on his contacts. Just for illustration of the fate of archaeologists of Lvov in the intellectual life of Europe in the first half of XX century we give the list of cities with the scientists from which L. Kozłowski maintained close connections: Berlin, Tubingen, Guben, Dresden, Prague, Stuttgart, Munich, Vienna, Sofia, Paris, Brussels, London, Oslo, Copenhagen. The list can be continued. This contacts were built during studies, research projects, international congresses. In the card catalogue of L. Kozłowski remained a huge number of publications with autographs, most of which from A. Breuil, R. Schmidt, G. Childe. All those people whose names kept by card catalogue of L. Kozłowski stored in Lvov, were not just the authors of articles which accidentally appeared in the collection, but good friends, colleagues of archaeologist from Lvov and had a direct impact at the archaeological environment of Lvov till the middle of XX century. 


\section{SCIENTIFIC COOPERATION WITH ARCHAEOLOGISTS OF KRAKóW}

Perhaps it is no exaggeration to say that the most extensive and fruitful cooperation archaeologists of Lvov established with colleagues from Kraków. This, above all, was contributed by the political situation. In fact, after the first partition of Poland (1772) Galicia was joined to the Empire of Habsburgs. It was created the separate province "Kingdom of Galicia and Lodomeria" which included not only Ukrainian ethnic territories (Eastern Galicia), but also the southern part of Poland with Kraków (Western Galicia). This political situation also influenced on development of archaeological science, particularly - cooperation between researchers of antiquities from Lvov and Kraków. In general, this cooperation was quite effective. But often some issues appeared, mostly connected with national problems.

This cooperation begins in 1848 when in Zbrucz River Światowid was accidentally discovered. On the initiative of Konstantyn Zaborowski - the owner of Liczkowce - Zbrutsky idol was moved to Mieczysław Potocki an amateur of antiquities, who in future became a conservator of sites, from neighboring Kociubińczyki. The last one in 15 of November, 1850 sent a letter with description of the find to Kraków a Scientific Society. To his estate arrived Teofil Żebrawski (1800-1887) (fig. 9), the author of works on engineering, mathematics, archeology, history, literature, who examined the find and prepared it for transporting. T. Żebrawski was one of the first who established connections with archaeologists from Lvov. In particular, he maintained contact with the first Ukrainian researcher of Zbrutsky idol - Antoni Petruszewicz. Petruszewicz's article Vestny 'k dlya rusy'nov Avstry 'jskoj derzhavy', published at the Vienna newspaper „Herald for the Ruthenians of Austrian country” was immediately sent to Kraków (where Zbrutsky idol was exhibited) for T. Żebrawski. In correspondence of Iwan Hołowacki with Antoni Petruszewicz information remained about the exchange by publications between these two researchers of Zbrutsky idol (Kril` 1999: 350-372, lyst 2-3).

In the collection of A. Petruszewicz (now owned by the Department of Rare Books of Stefanyk National Scientific Library of Ukraine in Lvov) copy of the book Wiadomość o bożyszczu stowiariskiem znalezionem w Zbruczu r. 1848 is stored. It was published in Kraków in 1858 and signed by the author - Wielmożnemu Panu Petruszewyczowi T. Żebrawski (Kril`1999: 372).

In the context of the examined questions scientific contacts of Dzieduszycki's museum seems interesting. The founder of the museum established cooperation with researchers from Kraków and developed it through their employees. In the archaeological collections of Dzieduszycki's museum, among others, materials 
from researches carried out by Adam Kirkor, Gotfryd Ossowski, Izydor Kopernicki are preserved.

W. Dzieduszycki in his activity assigned an important place for the protection of sites. From the 1860s he cooperated with Kraków Scientific Society in this field. In Kraków archives correspondence with the head of the society Józef Mayer (1808-1899) is stored. It is connected with issues of preservation of sites of Zhovkva (fig. 10) (Archiuwm PAN I PAU: TNK 80, k. 125).

In addition, scientific contacts can be traced between some employees of the archaeological department of the museum, including Władysław Przybysławski and Włodzimierz Demetrykiewycz.

W. Przybysławski was one of those, who supplied Dzieduszycki's museum by prehistoric finds at the turn of XIX/XX centuries. As a member of the Archaeological Imperial-Royal Commission of Conservators of Eastern Galicia, he prepared the publication of the first inventory of archaeological collections of the museum. He was also the guardian of the antique department of numismatic collection of the museum. W. Przybysławski corresponded with W. Demetrykiewycz (MAK).

In the last quarter of XIX century process of institutionalization of science is appeared. In all cities scientific societies were formed, which represented new level of the development of archeology - namely, the transition to Positivism. At this time, scientific contacts among scholars from the two parts of Galicia can be traced well.

It was emphasized repeatedly that archaeologists of Lvov had science as priority and often were members of several societies. Therefore, considering the scientific cooperation personalities are primarily taken into account, and only then institutions to which they belonged.

For example, in the activity of the Provincial archaeological Society (1875) scientific paths of researchers from Lvov and Kraków were very closely joined. Among its members were A. Petruszewicz, I. Szaraniewicz, A. Schneider and also Ż. Pauli, A. Kirkor and others. There can be talked a lot about scientific cooperation. Below only the most important examples are described.

Quite close scientific contacts existed between A. Schneider, who at that period carried out surveys in Ternopil' region, creates a letter books, and archaeologist from Kraków Józef Łepkowski (1826-1894), who in 14 of September 1875 became the state conservator of archaeological sites of the whole Galicia region. The relationship between two researchers can be traced on the base of mutual correspondence which is preserved in Lvov and Kraków.

This cooperation began near the end the 1860 s. A. Schneider sent publications to his colleague from Kraków, made lists of archaeological sites of Galicia, 
J. Lepkowski sent in response archaeological publications and also tried to persuade A. Schneider to the transfer of archaeological material from his private collection to the museum of the Kraków University (fig. 11) (PAK TSchn: 1054; LNNB: F. 144, op. V, spr. 13). Actually, A. Schneider was valuable source of information for supporting of protection of sites for J. Łepkowski, because at that time he worked on the "Encyclopedia of the local history of Galicia region" and perhaps better than other scientists from Lvov guided in the general situation with archaeological sites of Eastern Galicia

J. Łepkowski communicated not only with A. Schneider. His correspondence about findings of the first Myhalkiv hoard (1878) also seems interesting. Modern scientific interpretation of the last one, is quite completely reflected at the literature (Bandrivs'kyj, Krušel'nyc'ka 2012). Of course, such discovery as Myhalkiv hoard was very interesting for the conservator of archaeological sites of Galicia J. Łepkowski. From the documents we discover that conservator was not informed about the find, but read about it at Lvov newspapers. Of course, he was displeased by such situation, and it was reflected at the letter to the elder of Borshchiv. In October 28, 1878 the elder of Borschiv informs J. Łepkowski that golden hoard became the property of W. Dzieduszycki, and descript circumstances of the discovery in 17 of July, 1878 (PAK: GK 3, ark. 405, 413). Correspondence between J. Łepkowski and Ukrainian archeologist A. Petruszewicz was about the same topic, at one of the letters the last one sent his article about MykhalkivDnister golden hoard published in "Slovo" magazine in September 1878 (PAK: GK 3, ark. 373). Simultaneously, A. Petruszewicz mentioned his impressions from the exhibition of hoard in the city hall in Lvov, which took place in August 1878 and focuses on the fact that the security guards did not allow him to make neither description nor drawings, so posting is made by memories.

Among archaeologists who had close relations with the archaeological environment of Lvov another researcher from Kraków - Adam Kirkor (18181886) (fig. 12) should be mentioned. Quite effective cooperation between him and A. Schneider can be seen. It was connected, first of all, with the study of archaeological sites in Pokucia and Podola discovered by A. Schneider. At his letters, he asked A. Kirkor to carry out the professional investigation of these objects (Shnejder, 1995: 97).

An important event that influenced positively establishing of scientific contacts was the Congress of Ukrainian and Polish archeologists, which took place in September 1885 in city hall of Lvov. The invitation to participation at the Congress, dated by 28 of August, 1885 was sent by Wojciech Dzieduszycki to Józef Mayer (Archiwum PAN I PAU: 3170, t. 1, ark. 44). Initially the last one reported that he could not visit Lvov, but just before the Congress situation 
changed. Actually, J. Mayer was chosen as the Chairman of the Congress, his deputy was bishop Julian Pelesh, and the head of Ruthenian section - I. Szaraniewicz.

At the Congress in addition to I. Szaraniewicz and A. Petruszewicz such Ukrainian researchers reported as O. Ogonowski, J. Tselevych, delegation from Kraków was represented by A. Kirkor, G. Ossowski, T. Ziemięcki.

In parallel with the Congress archaeological exhibition was organized in Lvov Polytechnic Institute. Prehistoric part of it was presented by finds from researches, carried out by I. Szaraniewicz, A. Petruszewicz, A. Kirkor, G. Ossowski, T. Ziemięcki.

Results of the Congress shown that archaeologists from both centers and both parts of Galicia were open for debate of scientific issues and were able to reach a compromise in contrast to the politicians. The resolution of the Congress includes two main points: to demand from the authorities to found the Chair of archaeology and to increase protection of archaeological sites.

G. Ossowski deserves special attention. He was a member of the society, one of the correspondents of "Archeological review". He was invited to participate at the society by the letter signed by secretary K. Widmann.

Interesting documents which represent the further evidence of close contact with Lvov are remained in Torun. Specifically, the letter certifying that G. Ossowski established contacts with Lvov even before moving to Kraków. This fact is illustrated by gratitude for archaeological map to G. Ossowski sent on the blank of Ossolineum, which was find among the documents of researcher in Toruń (fig. 13) (APT, TNT 49, list 135, s. 117).

Izydor Kopernicki was delegated by the Kraków Academy of Sciences and Arts to Eastern Galicia, carried out research on eponym site in Verkhnia Lypytsia. He communicated and cooperated with A. Schneider. He made the analysis of human remains from excavations, carried out by I. Szaraniewicz and M. Hruszewski in Chekhy. Based on the results of these analysis he set anthropological type of this population.

Of course, W. Demetrykiewicz also has communications with Lvov and Eastern Galicia. He was conservator of sites, author of scientific publications about protection of cultural heritage. One of the most important archaeological researches of W. Demetrykiewicz also took place in Eastern Galicia - on the site Bilcz Złoty in Ternopil region. He was connected with Lvov by contacts with many scientists. However, not always these contacts were calm and friendly.

From his personal contacts K. Hadaczek's name is worth to be mentioned. RespectableprofessorcriticizedHadaczekhardly. Itis witnessedbycorrespondence of W. Demetrykiewicz with many archaeologists connected with person of K. Hadaczek and preserved in the archive of Kraków Archaeological Museum. 
So, the natural question appeared - whether excavations led by first professor of archaeology of Lvov University were carried out on such low methodical level, did he really lacked knowledge of prehistory and do not know contemporary scientific literature? Whether it was just a personal conflict between K. Hadaczek - young, ambitious enough, with European education and jurist by major field of study, the first pre-historian of Poland, a man with outstanding scientific heritage and also with some oddities - W. Demetrykiewicz? Whatever the answer was, based on numerous documents, we must recognize that this rather unsympathetic attitude existed during a long period of time. One of the problem issues in relations between the two professors was different visions of position of Gustav Kossina. It can be seen at the letters from W. Demetrykiewicz to E. Majewski, where focus often made on the fact that:

[...] among young representatives of science there are many supporters of Kossina and his ethnographic opinions. Professor Hadaczek from Lvov, unfortunately, is among such pests. In lectures and popular publications he promotes point of view of Kossina's doctrine [...] it is not good because bad grain thrown between youth is already growing $[\ldots]$ (PMA, t. 2, list 430).

Erazm Majewski also maintained contacts with Lvov. With great financial possibilities and significant scientific interest E. Majewski communicated with well-known scientists long before he begin to interest in archeology. He knows Karol Hadaczek and Benedykt Dybowski (Kozłowski 2009b: 9). Later, he established contacts with the Ukrainian institutions of Lvov. As it was mentioned by researcher M. Blombergowa, he sent to Szewczenko Scientific Society magazine "Światowit" famous in the scientific world (Blombergowa 1996: 96).

Criticism of K. Hadaczek of publication Pre-history of Galicia (1898) (Vorgeschichte Galiziens), written by W. Demetrykiewicz, who at that time was a prehistorian with great reputation played an important role at these hostile relations between two famous scientists (Hadaczek 1898-1899, see Woźny 2009: 39).

Despite the criticism of K. Hadaczek by W. Demetrykiewicz fairly polite working correspondence between them is remained at the archives (MAK). It is also seems that this criticism has no influence at the point of view of E. Majewski. It can be witnessed by the fact, that K. Hadaczek's scientific works continued to be published at the pages of "Światowit" magazine, edited by E. Majewski.

W. Demetrykiewicz also interested in activities of Lvov archaeologists in the period of World War I, when he was in Vienna and then in Switzerland (Woźny 2010: 181). Direct correspondence with Lvov archaeologists was not found, however, in letters of W. Antoniewicz repeatedly mentioned Lvov and 
colleagues from Lvov. At the one of letters last one with great regret writes about young and surprisingly talented Ukrainian archaeologist Włodzimierz Hrebeniak, who was killed near Halicz in 1915 (MAK: SP8/36).

Among the Ukrainian researchers Antoni Petruszewicz and Izydor Szaraniewicz were the members of the Academy of Sciences and Arts (since 1872), carried out an exchange by publications with researchers from Kraków and cooperated in the field. The most large-scale excavation organized by Ukrainian researchers was carried out in Halicz. These works allow us to follow a slightly different format of scientific relations. Specifically, during the researches of Halicz led by I. Szaraniewicz permission and funding for which he received from the authorities, conflict between I. Szaraniewicz and a.general conservator of sites W. Dzieduszycki took place (Bulyk 2009: 311-312).

W. Dzieduszycki was convinced that Ukrainian researchers have not enough experience for carrying out such large-scale work and offered to invite scientists from Kraków, but Szaraniewicz didn't agree with this and thus lose funding.

A positive aspect in this controversial situation was the fact that in 10 July 1883, during scientific seminar carried out by scientists from Lvov in medieval Halicz the idea appeared to organize Congress of archaeologists. From Kraków to the seminar was invited well-known researchers J. Lepkowski, A. Kirkor, P. Łuczkiewicz, J. Sokołowski and T. Ziemiencki. Delegation of scientists from Lvov was headed by professor I. Szaraniewicz. It included such famous experts as professor of Lvov Polytechnical institute architect J. Zacharewicz, K. Widmann.

Personal contacts with some archaeologists were maintained by I. Szaraniewicz during the next years. In particular, at the letter dated by 20 December 1888 he invited J. Łepkowski to visit archaeological bibliographic exhibition, conducted in Stavropigian Institute. Artifacts, presented at the exhibition are described in details, also notified that Stavropigian institute waiting for an occasion to send the catalogue of exhibition for colleagues (Archiuwm PAN I PAU: Rps PAN Kr. 3156).

Interestingly, photo of I. Szaraniewicz was found in the anniversary album made for J. Mayer by the members of academy. In addition, from 1897 I. Szaraniewicz was State conservator of historical sites of Eastern Galicia. In the field of protection of sites his activity intersected with W. Demetrykiewicz's one. One letter was written half a year before Szaraniewicz's death.

We can't trace contacts of Shevchenko Scientific Society with archaeologists of Kraków, however, correspondence of Demetrykiewicz includes a small card from F. Vovk sent from Lvov. 
In the same correspondence eight letters were found from Lvov archaeologist Bogdan Janusz dated back to 1911 and 1913 years. At these letters autor mentioned various archeological issues. At the one of the letters B. Janusz mentioned K. Hadaczek's work, and argues that classical archeology dominates at his publications. An interesting fragment is placed at the letter about Światowid from Łopuszany, written in Ukrainian. The writer presents figure of the find (fig. 14), and emphasizes the fact that photo was made by Wadym Szczerbakowski. B. Janusz continued to maintain contacts with archeologists from Kraków archaeological center in the next years.

The list of personal contacts between archaeologists from Lvov and Kraków can be continued. Summarizing can be emphasized that both archaeological centers from the middle of XIX century cooperated closely, archaeologists from the both parts of Galicia knew each other, shared experience and literature, correspond much and participated in joint research activities.

\section{Conclusions}

To sum up it should be noted that archaeologists from Lvov have quite close contacts with many scientists, which positively affected the formation and development of archeology science in Lvov. Rich amount of correspondence, preserved in various archives, gives a reason to believe that these contacts often spread beyond the official and had friendly character. Diverse scientific contacts facilitated borrowing of research methods, exchange of literature, filling of the museum collections. The studies and work with leading pre-historians of contemporary Europe influenced positively on the formation of archeology in Lvov. Exploring of the most important publications of that period had the undeniable importance for the development of science. So, we can certainly affirm that in libraries of Lvov researchers these works were presented (for example it can be witnessed by K. Hadaczek's prints in the collection of L. Kozłowski and other). The works of scientists from Lvov in its turn were sent to the different parts of Europe. It is not the exaggeration to claim that at the turn of XIX/XX century archaeologists of Lvov were the equal participants of the processes that took place in the European archaeology. In XIX century a solid foundation was created for cooperation that continues till now.

dr Natalia Bulyk

Instytut Ukrainoznawstwa im. I. Kripjakiewicza

Państwowa Akademia Nauk Ukrainy

nata_bnm@ukr.net 


\section{BibliograPhy}

Sources

Archiwum PAN I PAU, Archiwum Nauki Polskiej Akademii Nauk i Polskiej Akademii Umiejętności w Krakowie, Rękopis PAN Kr. 3156; Rkps PAN Kr. 3170, t.1, ark. 44; TNK (Towarzystwo Naukowe Krakowskie) sygn. 80, k. 125.

APT, TNT, Archiwum Państwowe w Toruniu, Towarzystwo Naukowe Toruńskie 49, list 135.

Catalogue..., Catalogue spécial de l'exposition des sciences anthropologiques. Exposition universelle internationale de 1878 à Paris, Paris 1878.

DALO, Deržavnyj arhiv Lvivskoi oblasti, F. 26 (L`vivs`ky`j universytet), op. 5, spr. 336 (Osobova sprava profesora Gadacheka), ark. 37.

Katalog..., Katalog Muzeum imienia Lubomirskich, Lwów 1877.

Kronika Towarzystwa..., Kronika Towarzystwa archeologicznego krajowego we Lwowie, „Przegląd Archeologiczny”, Lwów 1878, R. 1, z. II.

LNNB NAN, L'vìvs'ka nacìonal'na naukova biblìoteka Ukrainy imeni V. Stefanyka, F. 144 (Antoni Šnajder), op. V, spr. 31 (Materialy iz zagal'nyh pytan' archeologiï), ark. 100.

MAK, Muzeum Archeologiczne w Krakowie, Dział dokumentacji naukowej, Teczka listów W. Antoniewicza do W. Demetrykiewicza, SP8/36; Teki listów E. Majewskiego, T. 2, list 430.

PAK, GK, Państwowe Archiwum w Krakowie, Grono Konserwatorów Galicji Zachodniej w Krakowie, sygn. 2; sygn. 3.

PAK, TSchn, Państwowe Archiwum w Krakowie, Teki Antoniego Schenidera, sygn. 1050.

PMA, Państwowe Muzeum Archeologiczne w Warszawie, Teki listów Erazma Majewskiego, t. 2, list 430.

Py`s ‘menny`ky`..., Pys'mennyky Zahidnoï Ukraïny 30-50 rokiv XIX st., Kyïv 1965.

Literature

Abramowicz A. (1974), Dalecy i bliscy. Szkice z dziejów archeologii, ŁTN, Ossolineum, Łódź-Wrocław.

Abramowicz A. (1991), Historia archeologii polskiej XIX i XX wiek, IHKM PAN, Warszawa-Lódź.

Bandtivs'kyj M., Krušel'nyc'ka L. (2012). Zoloti Myhalkivs'ki skarby ta ïh dolia. L'viv. 
Berest R. (1998), Karlo Gadachek: štryhy biografii ta naukovoï diâlnosti. Postati ukraïns'koï archeologiï, „Materialy ta doslidžnnâ z arheologiï Prykarpattâ ta Volyni”, vyp. 7, s. 78-79.

Blombergowa M. (1996), O kontaktach naukowych Erazma Majewskiego, [w:] Erazm Majewski $i$ warszawska szkoła przedhistoryczna na poczatku XX wieku, red. S. K. Kozłowski, J. Lech, Warszawa, PWN, Warszawa, s. 93-96.

Brézillon M. (1969), Dictionnaire de la préhistoire, Librairie Larousse, Paris.

Bulyk N. (2008a), Archeologični kolekciï u muzeâh Lvova, „Materialy ta doslidžnnâ z archeologiï Prykarpattâ ta Volyni”, vyp. 12, s. 407-428.

Bulyk N. (2008b). Archeologični oseredky L'vova (1875-1914): naukovi pošuky ta poliovi zdobutky, „Archeologični doslidžennâ L'vivs'kogo universytetu”, vyp. 11, s. 209-237.

Bulyk N. (2009), Formuvannâ ukraïns'koï archeologï v Galyčyni u XIX stolitti: Isydor Šaranevyč (1829-1901), ,Materialy ta doslidžnnâ z archeologiï Prykarpattâ ta Volyni”, vyp. 13, s. 307-321.

Bulyk N., Lech J. (2009-2011), Karol Hadaczek (1873-1914) and the begginnings of archaeology in universities of the North-East borderland of the AustroHungarian Monarchy, „Archaeologia Polona”, vol. 47, s. 59-89.

Burdulanûk V. (2009), Muzë̈ Naukovogo tovarystva imeni Ševčenka, „Visnyk Prykarpatskogo Universytetu. Istoriâ", Ivano-Frankivs'k, vyp. XV, s. 3-10.

Hadaczek K. (1898-1899), Kilka uwag o czasach przedhistorycznych Galicyi, „Eos”, t. 5, s. 55-61.

Hadaczek K. (1914), Osada przemysłowa w Koszyłowiczach z epoki eneolitu, Lwów.

Franko O. (1997), Diâl'nist' Fedora Vovka v Naukovomu tovarystvi im. Ševčenka, [w:] Z istoriï Naukovogo tovarystva imeni Ševčenka. Zbirnyk dopovidej i povidomlen' naukovyh sesij Naukovogo tovarystva imeni Ševčenka u L'vovi, L'viv, s. 84-101.

Franko O. (2001), Fedir Vovk - včenyj i gromads'kyj diâč, Kyïv.

Karolczak K. (2001), Dzieduszyccy. Dzieje rodu. Linia poturzycko-zarzecka, Wydawnictwo Naukowe AP, Kraków.

Klejn L. (2011), Istoryâ archeologičeskoj mysli, t. 1, Sankt Peterburg.

Kozłowski S. K. (2006), Volodymyr Antonêvič i Karol'Gadaček, „Archeologični doslidžennâ L'vivs'kogo universytetu', vyp. 9, s. 89-96.

Kozłowski S. K. (2009a), Włodzimierz Antoniewicz, profesor z Warszawy, PMA, Warszawa.

Kozłowski S. K. (2009b), Apostołowie okresu formatywnego Warszawskiej Archeologii, [w:] Księga Pamiatkowa I Zjazdu Absolwentów Archeologii Uniwersytetu Warszawskiego, Stowarzyszenie SiA IA UW ARCHEO, Warszawa, s. 7-15. 
Kril` M. (1999), Nevidomi lysty Ivana Golovackogo do Antona Petruševyča, „Ukraïna moderna", čast. 2-3, s. 350-372.

Kubijovyč V. (1991), Narys istorï NTŠ (1873-1949), L'viv.

Lech J. (1999), Between Captivity and Freedom. Polish Archaeology in the $20^{\text {th }}$ Century, Arwil, Warsaw.

Lech J. (2006), Z istoriyi pol 's 'ko-ukrayins 'ky ’x zv'yazkiv v arxeologiyi (kinecz 'XVIII st.-1939 r.), „Archeologichni doslidzhennya L`vivs`kogo universy`tetu”, vy` p. 9, s. 17-53.

Lèger L. (1877), Rapport à Son Excellence le Ministre de l'Instruction Publique sur une mission scientifique près le congrès archèologique de Kiev, „Extrait des Archives des missions scientifiques et littéraires. $3^{\mathrm{e}}$ série", vol. IV.

Maternicki J., Zaszkilniak L. (red.) (2007), Złota księga historiografii lwowskiej XIX i XX wieku, Rzeszów.

Naulko V. (2006), Lysty Lûbora Niderle do Myhajla Grušews'kogo, „Ukraïns'kyj archeografičnyj soričnyk", vyp. 10/11, s. 631-639.

Pasternak Â. (1961), Archeologiâ Ukrä̈ny, Toronto.

Pasternak Â. (1962), Ti so rozkryly pidzemnuj arhiv Ukrä̈ny (Pam'âti vydatnyh archeologiv Ukraïny), „Terem”, R. I, čast. I, s. 7-12.

Petegyryč V. M. (1996), Dolâ archeologičnyh kolekcij muzêิ NTŠ, „Biblioteka Naukowogo tovarystva im. Ševčenka: knygy i lûdy", s. 59-67.

Podgórski W. (1875), Antoni Sznejder autor „Encyklopedii do krajoznawstwa Galicyi”, „Kłosy”, nr 504, t. XX, s. 115-118.

Rudyns'kyj M. (red.) (1931). Mizyn. Vyznačniši serï kistânyh vyrobiv Mizyns'koï paleolityčnoï stacyï v osvitlenni Fedora Vovka, Kyïv.

Radiêvs'ka T. M. (2012), Archeologiâ u naukowomu dorobku Hfedora Vovka, materialy jogo doslidžen' u zibranni Nacional'nogo muzê̂ istorï Ukraïny, „Archeolohiâ i davnâ istoriâ Ukraïny. Istoriâ archeologiï: doslidnyky ta naukovi centry", vyp. 9, s. 213-220.

Renfrew C., Bahn P. (2002), Archeologia: Teorie, metody, praktyka, Prószyński i S-ka, Warszawa.

Sadowski J. N. (1877), Sprawozdanie z posiedzeń ósmego międzynarodowego kongresu antropologiczno-archeologicznego w Peszcie w 1876 r., „Rozprawy i sprawozdania z posiedzeń wydziału historyczno-filozoficznego Akademii Umiejętności”, (dodatek), Kraków, t. VI, s. I-XXVI.

Schneider A. (1877), Sprawozdanie z odbytego w Buda-Peszcie kongresu Archeologicznego w r. 1876, „Przegląd Archeologiczny”, t. I, z. 4, s. 117-127. 
Shnejder A. (1995), Borshhivs `ky’j povit u Galy'chy`ni z jogo doistory`chnoyu ta seredn 'ovichnoyu starovy `noyu (Archeologichne doslidzhennya opracz 'ovane na misci u 1878 r.), „Litopy`s Borshhivshhy`ny””, vy`p. 7, s. 84-99.

Sklenář K. (1983), Archeology in Central Europe: the First 500 Years, Leicester University Press and St. Martin Press, Leicester-New York.

Sytnyk O. S. (1999), Hvedir Vovk - pershyj profesijnyj doslidnyk paleolitu Ukraïny, „Archeologična zbirka Hersons'koï inspekciï ohorony pam'âtok”, 1, Herson, s. 64-79.

Sytnyk O. S. (2012), Archeologična nauka u L'vovi. Perša polovyna XX stolittâ, L'viv-Žešiv.

Trigger B. (1989), A history of archaeological thought, University Press, Cambridge.

Vagylevyč I. (1928), Lyst do P.J. Šafaryka, [w:] Korespondence Pavla Josefa Šafařika, t.1, Část 2. Vzájemné dopisy P.J. Šafařika s ruskými učenci (1825-1861), vyd. V. A. Francev, Česká Akademie Věd a Uměni, Praha.

Vilímek J. (1890-1891), České album. Sbírka podobizen předních spisovatelì a spisovatelek českých, učenců, mužů i žen práce, kteř́ život svioj zasvětili povznesení národa svého, Praha.

Vovk F. (1905), Vyroby peredmikens'kogo typu na Ukraïni, „Materialy do ukraïns'korus'koï etnologiï', t. 4, s. 1-27.

Woźny M. (2009), Włodzimierz Demetrykiewicz (1859-1937): the fierst prehistorian from Cracow. On his 150 th birthday anniversary, „Archaeologia Polona”, vol. 47 , p. 33-58.

Woźny M. (2010), Włodzimierz Demetrykiewicz (1859-1937) - pierwszy prehistoryk z Krakowa, „Materiały Aarcheologiczne”, t. XXXVIII, s. 175-192. 


\title{
STRESZCZenie
}

\section{ARCHEOLODZY ZE LWOWA W TWORZENIU EUROPEJSKIEGO ŚRODOWISKA INTELEKTUALNEGO OD POŁOWY XIX W. DO PIERWSZEJ ĆWIERCI XX W. (WSPÓŁPRACA BEZPOŚREDNIA I POŚREDNIA)}

\begin{abstract}
Rozwój nauki nie jest możliwy bez współpracy, wymiany doświadczeń, a nawet przyjaźni między badaczami. Archeologia, która w XIX wieku przeszła długą drogę od hobby do dyscypliny naukowej, nie była pod tym względem wyjątkiem. Jak zauważył J. Pasternak na łamach „Archeologii Ukrainy”, w połowie XIX wieku na Ukrainie działały trzy główne ośrodki archeologiczne - lwowski, kijowski i odesski (Pasternak 1961: 18). W przeciwieństwie do Kijowa i Odessy, Lwów był częścią Cesarstwa Austriackiego, archeologia rozwijała się więc tam podobnie jak w innym ośrodku naukowym Galicji, tj. w Krakowie. Specyfiką Lwowa było współistnienie zarówno ukraińskich jak i polskich ośrodków archeologicznych. Celem autorki jest poszukiwanie aktywności archeologów lwowskich w tworzeniu europejskiej przestrzeni intelektualnej. Analiza dokumentów pozwala stwierdzić, że archeolodzy lwowscy współpracowali z uczonymi z niemal całej Europy (szczególne stosunki łączyły ich z badaczami z Krakowa). Ponadto należy zauważyć, że relacje te pojawiły się nie tylko między instytucjami, ale również na poziomie stosunków osobistych.
\end{abstract}



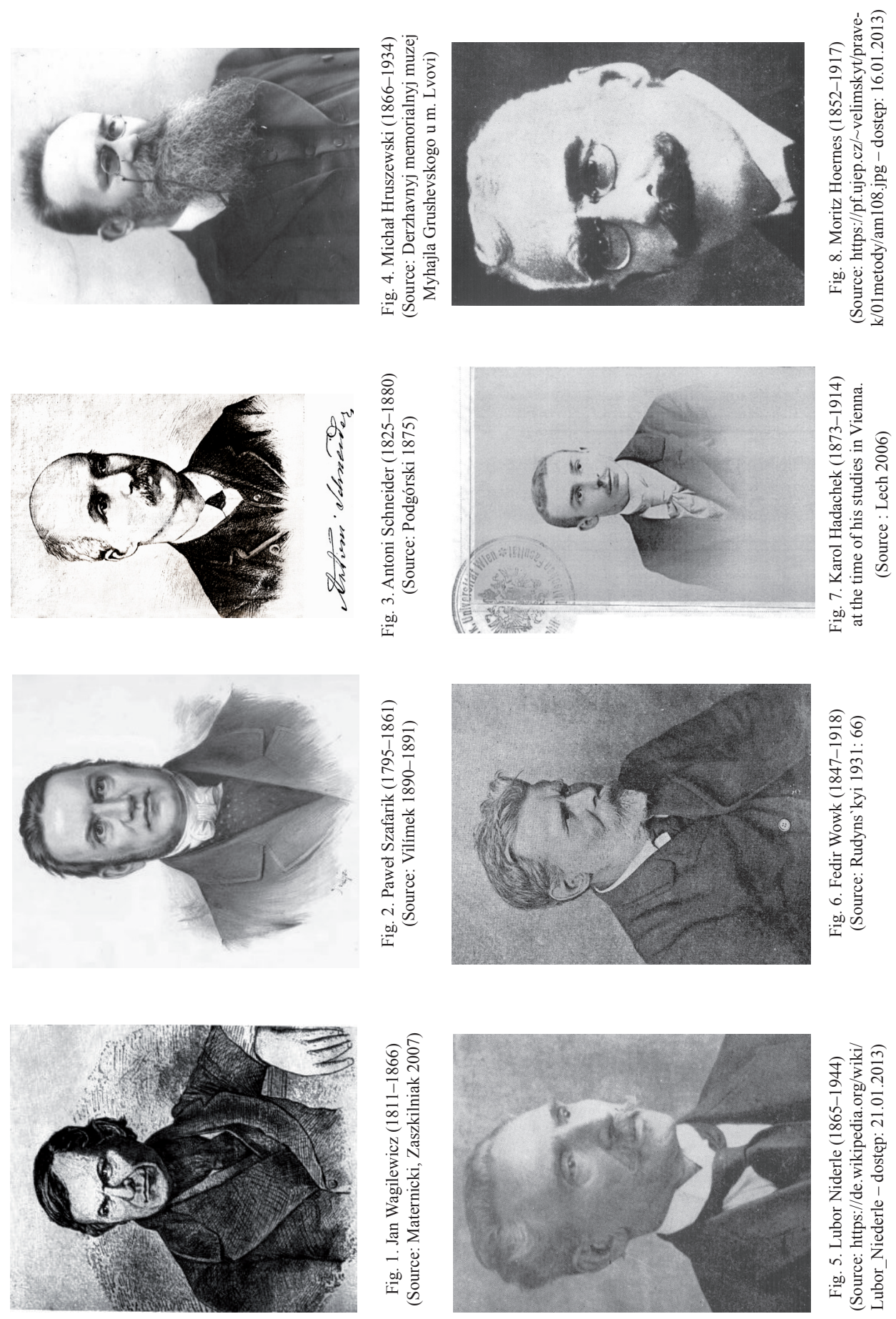


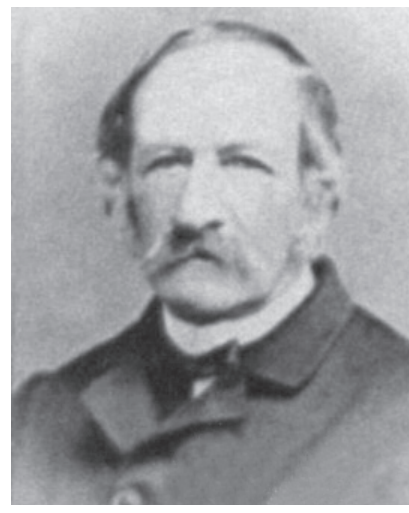

Fig. 9. Teofil Żebrawski (1800-1887) (Source: http://www.genealogia.okiem.pl/foto2/ displayimage.php?album=1\&pid=41613\#top_ display_media-dostęp: 24.01.2013)

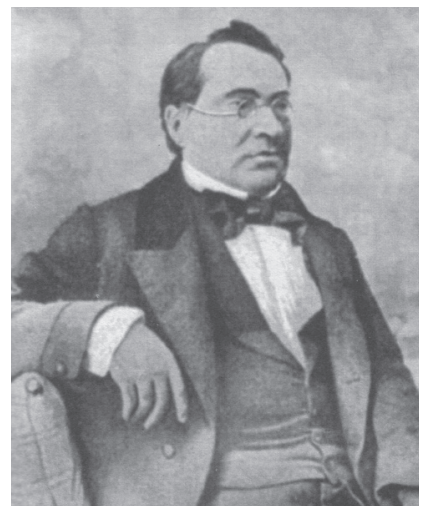

Fig. 10. Adam Kirkor (1818-1886)

(Source: http://www.russianresources.lt/archive/ Vilnius/Kirkor_0.html - dostęp: 05.01.2009)
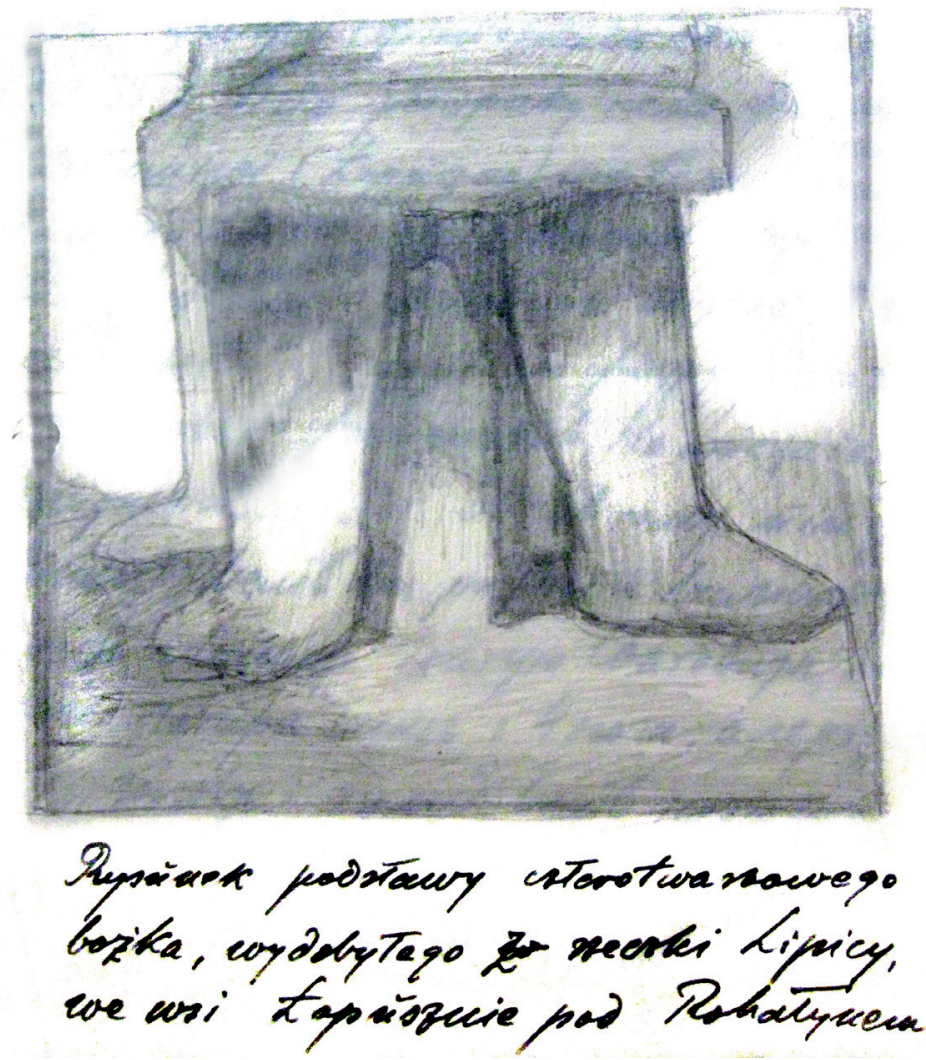

Fig. 11. Bogdan Janusz's picture. From the letter to Włodzimierz Demetrykiewicz (Source: MAK) 
216

Natalia Bulyk

GABINET

KATEDRY ARCHEOLOGII

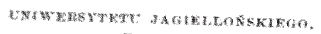

Do
Tration t. Ckerw 1875

w Collegium Jagellonicum.

Aojntiana

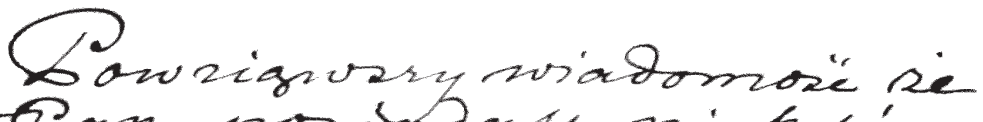
wban poubaly miektóne preamioby 2 minopatiak, alk: 位 Arremierme, hamieme, zabythi bronkowe ete; oimielam liq nasungí a ranow nemn bam moug: re niemi iforiythiem dia nanki sbogaic' moiess sbiós masey numerisytetu, o co npme

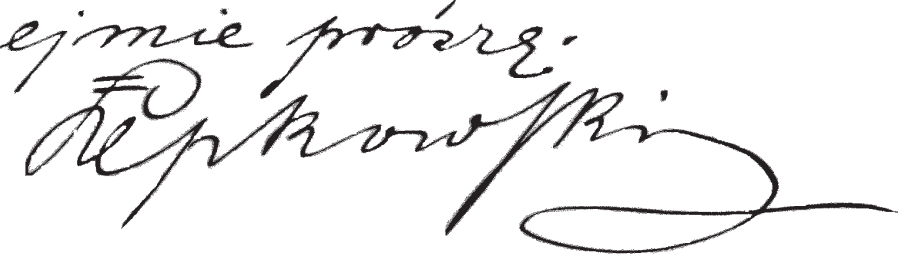

Fig. 12. Józef Łepkowski’s letter to Antoni Schneider about transfer of archaeological finds (Source: LNNB NAN) 


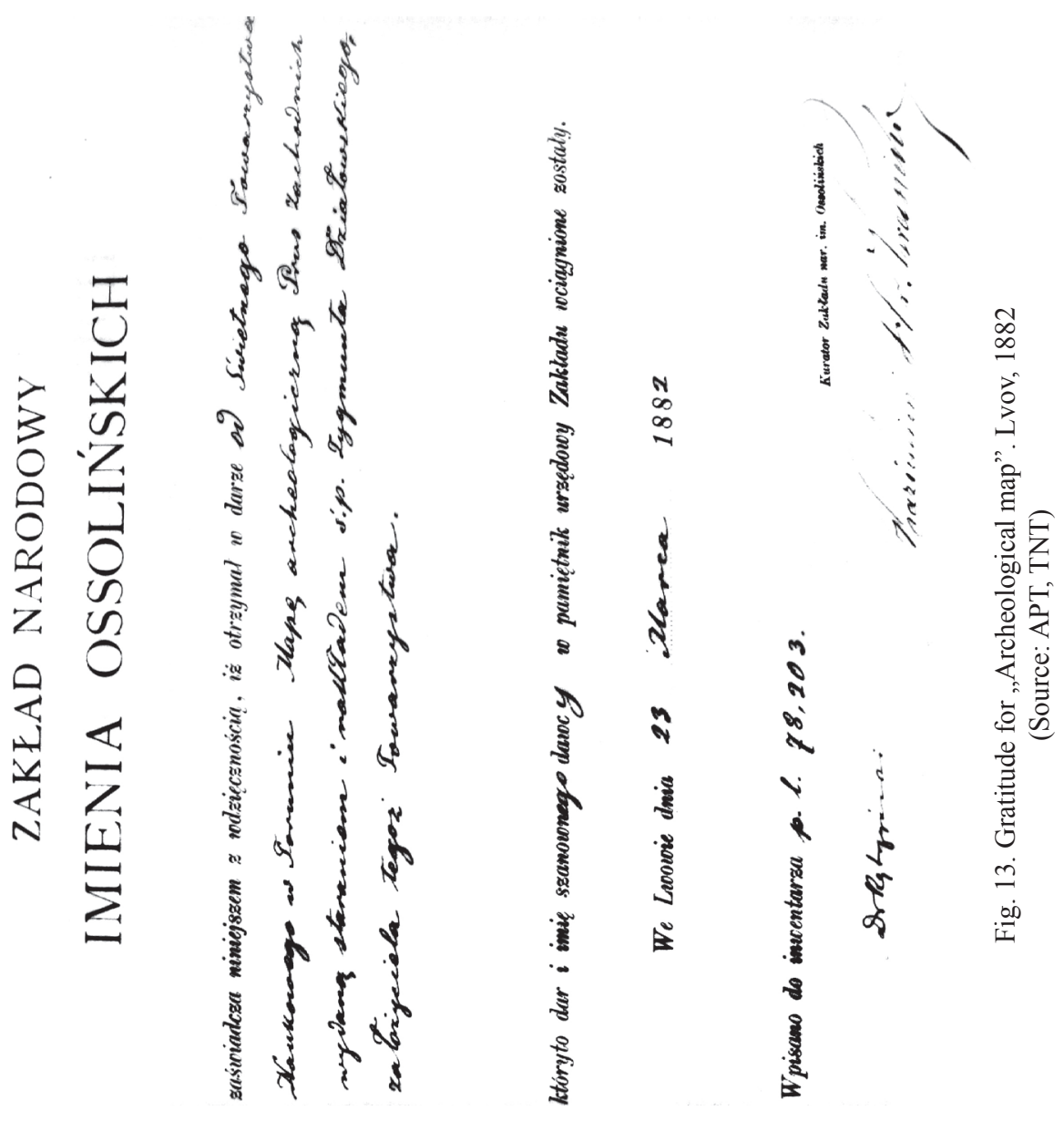




\section{Cranoning Meresie.'}

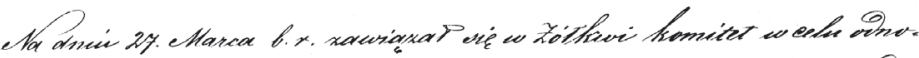

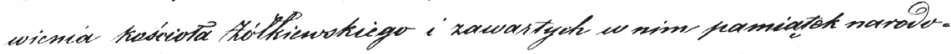
wyeh.

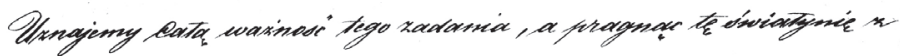

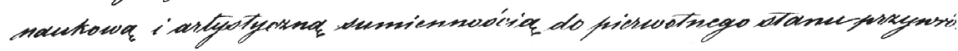

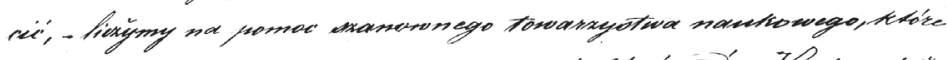

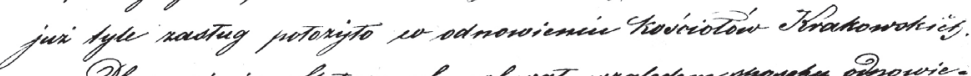

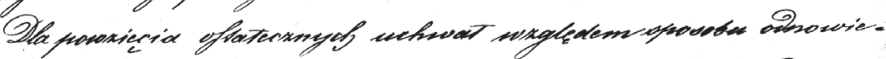

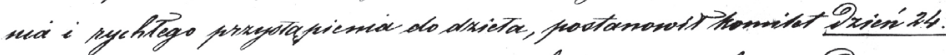

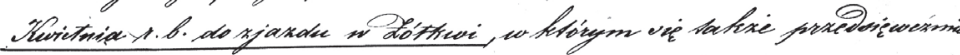

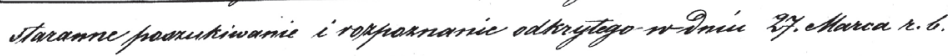

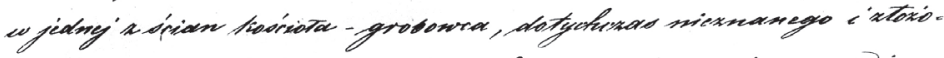

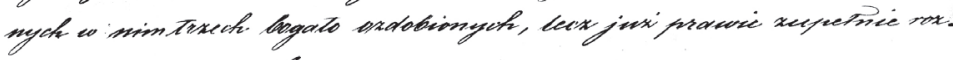

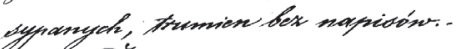

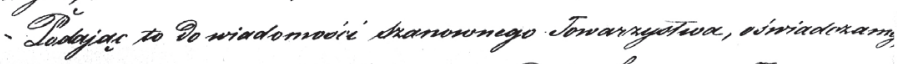

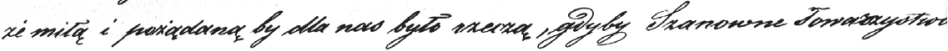

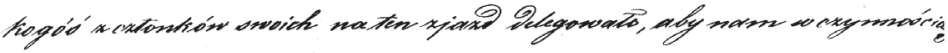

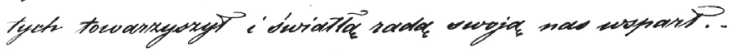

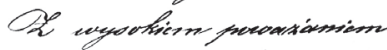
To prexeda homitcte

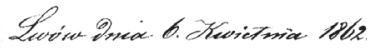

$$
\text { Ghtorimier Drienmaryik }
$$

Fig. 14. Włodzimierz Dzieduszycki’s letter to Jozef Majer about preservation of sites in Zhovkva, (Source: Archiwum PAN I PAU, TNK) 